\title{
EVALUATION OF COLOUR IN SERRA DA ESTRELA CHEESE PRODUCED IN DIFFERENT DAIRIES ALONG THE MILKING SEASON
}

\author{
Raquel P. F. Guine ${ }^{1 *}$, Luisa Fontes ${ }^{2}$, Maria Joao Lima ${ }^{1}$ \\ 1* CI\&DET and CERNAS Research Centers, Polytechnic Institute of Viseu, Viseu, Portugal, e-mail: raquelguine@esav.ipv.pt \\ ${ }^{2}$ Department of Food Industry, Agrarian School, Polytechnic Institute of Viseu, Viseu, Portugal
}

\begin{abstract}
The objective of the present work was to compare the colour of Serra da Estrela Cheese manufactured in different dairies. The samples used for the study were obtained from 6 dairies situated in PDO region for Serra da Estrela cheese: Sabores \& Ambientes (Oliveira do Hospital), Casa Agrícola dos Arais (Celorico da Beira), Casa da Ínsua (Penalva do Castelo), Queijaria de Germil (Penalva do Castelo), Quinta de São Cosme (Gouveia), Quinta da Lagoa (Nelas). The colour measurements were made using a colorimeter that registered the values of the Cartesian coordinates in CIELAB colour space: $L^{*} a^{*} b^{*}$. To evaluate the colour of each producer along the milking season and the colour difference was then calculated. The results obtained in this work indicated that the colour characteristics of the Serra da Estrela Cheeses are slightly different between samples coming from different dairies where the cheeses were manufactured. Nevertheless, in the beginning of data collecting the values of the colour coordinates varied in a limited range, which means that the variations could be considered acceptable attending to the nature of the traditional manufacture process associated with this PDO product. Furthermore, the results showed that along the milking season very important changes in colour took place. However, these changes were found very much dependent of the dairy, as the results of total colour change demonstrated.
\end{abstract}

Keywords: colour properties, lightness, quality, traditional cheese

\section{Introduction}

The "Serra da Estrela" cheese is a traditional Portuguese cheese, with a very ancient history, being presently one of the most valued products, much appreciated due to its particular sensory characteristics like smooth texture. For its production, only three key ingredients are used: ewe's milk, salt and dried thistle flower (Cynara cardunculus L.); the last used for the coagulation of the milk. The manufacture process remains very similar to that used in the old days, being for that reason classified as a PDO (Protected Designation of Origin) product according to the European Union and Portuguese regulations (Carocho et al., 2016a, 2016b).

Serra da Estrela cheese is recognized as a unique highquality type of cheese, produced with raw milk obtained from sheep of the autochthonous breed "Bordaleira Serra da Estrela". Nevertheless, some less conscious producers might use a mixture of Bordaleira Serra da Estrela ewe's milk with cheaper and / or low-quality milk from other more productive breeds, leading to increase cheese yield and lower products costs. This is why the certification of the producers is so important and allows controlling quality of the products along the entire chain, from raw-materials to the final cheese, also guarantying traceability (Cunha et al., 2016).

This Portuguese delicacy is the most famous cheese produced in the country, being also much appreciated worldwide, with exports rising by the year. Because it is preferentially consumed as a soft cheese, the usual time to achieve that texture is 4 weeks of ripening. Nevertheless, some prefer to consume the Serra da Estrela Cheese as a hard cheese after a minimum of 6 months of storage, being this called Old Serra da Estrela Cheese (Carocho et al., 2016b; Reis, Malcata, 2011).

The characteristic colour of Serra da Estela Cheese is light yellow, varying according to maturation time and storage conditions, as well as with manufacturing process and characteristics of the raw milk used, namely the homogenization of the casein micelles in the raw milk and the native microbiota. For this reason, the objective of the present work was to compare the colour of Serra da Estrela Cheese manufactured in different dairies and to evaluate the evolution of the colour along the milking season.

\section{Materials and Methods \\ Samples used for the study}

The samples used for the study were obtained from 6 dairies situated in PDO region for Serra da Estrela cheese production: Sabores \& Ambientes (Oliveia do Hospital), Casa Agrícola dos Arais (Celorico da Beira), Casa da Ínsua (Penalva do Castelo), Queijaria de Germil (Penalva do Castelo), Quinta de São Cosme (Gouveia), Quinta da Lagoa (Nelas). At each of the 4 evaluation moments, 5 cheeses were collected from each dairy.

\section{Milk production}

The cheeses used for analyses were produced from ewe's raw milk, coagulated with an aqueous extract of dried thistle, and the maturation time was 45 days in all cases. The cheese manufacture followed the traditional process. The milk is heated to $28-32{ }^{\circ} \mathrm{C}$ and salted, then vegetable rennet for coagulation is added - the wild thistle flower $(0.3 \%)$, previously grounded with salt. After 60 minutes, the curd is manually cut and a new filtration is done to remove the remaining serum. Once the steps of moulding, pressing and new salting have taken place, maturation follows.

The milk used for the Serra da Estrela cheese comes from manual milking and is filtered through a white cloth. Salt and vegetable rennet (dried wild thistle flower) is added to heated milk $\left(30^{\circ} \mathrm{C}\right)$. After 45 to 60 minutes the curd is manually cut and filtered to remove the remaining whey. Then follow the steps of moulding, pressing and salting of the surface, and finally the cheese is ready for maturation, being turned and 
washed every day with water for the first 15 days and then more sporadically until the end of the ripening process. The maturation times were 45 days for all samples collected in the different dairies.

\section{Colour measurement}

Along the milking season the colour of the cheeses' rind was evaluated, on a monthly basis, with measurements made in March (month 1), April, May and June (month 4), i.e., with a 30 days' interval. For each dairy 5 cheeses were considered for evaluation and 20 colour measurements were made in each cheese (10 at top side and 10 at bottom side) to allow calculating the mean value and standard deviation.

The colour measurements were made with a colorimeter CR-400 (Konica Minolta) using the Cartesian coordinates in CIELAB colour space: $L^{*}=$ lightness, $\mathrm{a}^{*}=$ green $/ \mathrm{red}, \mathrm{b}^{*}=$ blue / yellow. While lightness ranges from 0 (black) to 100 (white), $a^{*}$ and $b^{*}$ are the opposing colour coordinates ranging from -60 (green / blue, respectively) to +60 (red / yellow, respectively) (Guiné et al., 2014; Guiné et al., 2015).

To evaluate the colour difference in relation to the reference, considered at the beginning of maturation, the colour difference $(\Delta \mathrm{E})$ was calculated by Equation (1) (Valdivia-López and Tecante, 2015):

$$
\Delta E=\sqrt{\left(\Delta L^{*}\right)^{2}+\left(\Delta a^{*}\right)^{2}+\left(\Delta b^{*}\right)^{2}},
$$

where each term is the difference between the colour coordinate of the reference and the material.

A larger $\Delta \mathrm{E}$ denotes a greater colour difference from the reference material. A typical scale for evaluation of the colour difference is this: $\Delta \mathrm{E}$ in the range [0.0-2.0] corresponds to unrecognizable differences, in the range [2.0-3.5] corresponds to differences possible to recognize by an experienced observer and over 3.5 corresponds to clear differences of colour (ValdiviaLópez, Tecante, 2015).

The Cartesian coordinates were also used to calculate the polar or cylindrical coordinates, in the Munsell colour system: Value (V), Hue angle $\left(\mathrm{H}^{\circ}\right)$ and Chroma or saturation (C), as defined by equations (2) to (4):

$$
\begin{aligned}
& \left\{\begin{array}{l}
H^{o}=\operatorname{arctg}\left(b^{*} / a^{*}\right), \text { for } a^{*}>0 ; b^{*}>0 \\
H^{o}=180^{\circ}+\operatorname{arctg}\left(b^{*} / a^{*}\right), \text { for } a^{*}<0 ; b^{*}>0 \\
H^{o}=270^{\circ}+\operatorname{arctg}\left(b^{*} / a^{*}\right), \text { for } a^{*}<0 ; b^{*}<0 \\
H^{o}=360^{\circ}+\operatorname{arctg}\left(b^{*} / a^{*}\right), \text { for } a^{*}>0 ; b^{*}<0
\end{array}\right. \\
& C=\sqrt{a^{*}+b^{* 2}} \\
& \mathrm{~V}=\mathrm{L} * / 10
\end{aligned}
$$

\section{Statistical analysis}

To evaluate whether the results obtained in terms of mean value were statistically different between samples a statistical analysis was applied. The Post-Hoc Tukey HSD (Honestly Significant Difference) test was used with coupled to an analysis of variance (ANOVA) for comparison between three or more groups. Tukey's is a statistical test to identify the differences among groups of data and consists of a single multi-step process for comparison, carried out in conjunction with ANOVA. The test identifies where the difference between two mean values is higher than the standard error which could be expected. For statistical analysis was used the statistical software SPSS version 25 (IBM, Inc.) and the level of significance considered was $5 \%(\mathrm{p}<0.05)$.

\section{Results and Discussion}

\section{Comparison between dairies}

Table 1 shows the results obtained for Cartesian colour coordinates of the cheeses obtained from the six dairies included in the study, in March, the high season of Serra da Estrela cheese production. The values obtained for lightness $\left(\mathrm{L}^{*}\right)$ are in the range 56.84-67.82, indicating that the samples have a clear colour, since the values are over 50 and therefore closer to the white $\left(\mathrm{L}^{*}=100\right)$ than black $\left(\mathrm{L}^{*}=0\right)$. When the samples were compared using ANOVA, significant differences were observed in lightness, with the sample QC being the darkest and sample SA the lightest. Furthermore, the results indicate that the differences in lightness explained almost $90 \%$ of the variance observed, which is very much relevant.

Table 1

Cartesian colour coordinates of the cheeses in March (first month of the evaluation period)

\begin{tabular}{lccc}
\hline Dairy $^{1}$ & $\mathbf{L}^{* 3}$ & $\mathbf{a}^{* 3}$ & $\mathbf{b}^{* 3}$ \\
\hline SA & $67.82 \pm 2.99^{\mathrm{d}}$ & $-2.28 \pm 0.55^{\mathrm{b}}$ & $25.88 \pm 1.16^{\mathrm{c}}$ \\
CA & $64.87 \pm 1.11^{\mathrm{c}}$ & $-2.82 \pm 0.17^{\mathrm{a}}$ & $28.11 \pm 0.77^{\mathrm{d}}$ \\
CI & $57.21 \pm 1.69^{\mathrm{a}}$ & $-0.11 \pm 0.82^{\mathrm{d}}$ & $25.64 \pm 2.12^{\mathrm{bc}}$ \\
QG & $64.37 \pm 0.81^{\mathrm{c}}$ & $-2.08 \pm 0.35^{\mathrm{b}}$ & $24.30 \pm 1.38^{\mathrm{b}}$ \\
QC & $56.84 \pm 0.91^{\mathrm{a}}$ & $-2.29 \pm 0.99^{\mathrm{b}}$ & $26.88 \pm 4.11^{\mathrm{cd}}$ \\
QL & $58.46 \pm 1.91^{\mathrm{b}}$ & $-1.61 \pm 0.38^{\mathrm{c}}$ & $19.62 \pm 1.78^{\mathrm{a}}$ \\
Statistics & & & \\
$F$ & 287.842 & 63.676 & 74.060 \\
p-value & $<0.0005$ & $<0.0005$ & $<0.0005$ \\
VE $^{2}(\%)$ & 89.57 & 59.80 & 61.28 \\
\hline
\end{tabular}

${ }^{1}$ SA: Sabores \& Ambientes, CA: Casa Agrícola dos Arais, CI: Casa da Ínsua, QG: Queijaria de Germil, QC: Queijaria de São Cosme, QL: Quinta da Lagoa.

${ }^{2}$ VE: Variance explained.

${ }^{3}$ Values with the same superscript in the same column are not significantly different $(\mathrm{p}<5 \%)$.

Regarding the opposing colour coordinate $\mathrm{a}^{*}$, also significant differences were obtained $(\mathrm{p}<0.0005)$, with the lowest value for the sample CA and the highest for sample CI (Table 2). For this parameter the values obtained were negative, which means that they stand in the green zone and not red (for which $a^{*}$ would be positive). Nevertheless, the values are quite near zero, and therefore the intensity of the green coloration is low, just a very slight tone. For a* the variance explained was a little lower, but still very relevant, approximately $60 \%$. For coordinate $b^{*}$ the values were positive and high, meaning that the samples were yellow (blue would be for negative $b^{*}$ ) and with a high intensity of the yellow colouration, varying from 19.62 (sample QL) to 26.88 (sample QC). Again these differences were statistically 
significant, and explained more than $60 \%$ in the variability of the property.

Table 2 shows the cylindrical coordinates of the analysed cheeses also in March, the first month of the evaluation period. Hue corresponds to the distinction between colours when positioned around a colour wheel, denominated as the Hue wheel, varying from $0^{\circ}$ to $360^{\circ}$. Hue changes according to the angle, i.e., as it is moved around the centre. For $\mathrm{H}^{\circ}=0^{\circ}$ is red, for $\mathrm{H}^{\circ}=60^{\circ}$ is yellow, $\mathrm{H}^{\circ}=120^{\circ}$ is green, $\mathrm{H}^{\circ}=180^{\circ}$ is cyan, $\mathrm{H}^{\circ}=240^{\circ}$ is blue, $\mathrm{H}^{\circ}=300^{\circ}$ is magenta, $\mathrm{H}^{\circ}=360^{\circ}$ is red. The values obtained for Hue in the present work are near $180^{\circ}$, meaning they correspond the transition between green and cyan.

Table 2

Cylindrical coordinates of the cheeses in March (first month of the evaluation period)

\begin{tabular}{lcc}
\hline Dairy $^{1}$ & $\mathbf{H}^{\mathbf{0 3}}$ & $\mathbf{C}^{\mathbf{3}}$ \\
\hline SA & $178.52 \pm 0.02^{\mathrm{a}}$ & $25.99 \pm 1.15^{\mathrm{c}}$ \\
CA & $178.53 \pm 0.01^{\mathrm{a}}$ & $28.25 \pm 0.77^{\mathrm{d}}$ \\
CI & $179.69 \pm 1.55^{\mathrm{b}}$ & $25.64 \pm 2.11^{\mathrm{bc}}$ \\
QG & $178.51 \pm 0.01^{\mathrm{a}}$ & $24.39 \pm 1.39^{\mathrm{b}}$ \\
QC & $178.68 \pm 0.67^{\mathrm{a}}$ & $27.00 \pm 4.04^{\text {cd }}$ \\
QL & $178.51 \pm 0.02^{\mathrm{a}}$ & $19.69 \pm 1.78^{\mathrm{a}}$ \\
Statistics & & \\
$F$ & 16.534 & 76.684 \\
-value $_{\text {VE }}^{2}(\%)$ & $<0.0005$ & $<0.0005$ \\
\hline
\end{tabular}

${ }^{1} \mathrm{SA}$ - Sabores \& Ambientes, CA - Casa Agrícola dos Arais, CI - Casa da Ínsua, QG - Queijaria de Germil, QC - Queijaria de São Cosme, QL - Quinta da Lagoa.

${ }^{2} \mathrm{VE}$ : Variance explained.

${ }^{3}$ Values with the same superscript in the same column are not significantly different $(\mathrm{p}<5 \%)$.

The Chroma is the quality of the colour's purity, corresponding to its intensity or saturation, and changes when moving from the centre (where the saturation is minimum) in the direction of the periphery (where the saturation is maximum). There is no definite upper limit for the values of Chroma, and different areas of the colour space can have different maximum Chroma coordinates. For example, light yellow colours have considerably more potential Chroma than light purples, due to the nature of the eye and the physics of colour stimuli. As a consequence, a wide range of possible Chroma levels exist, up to the high $30 \mathrm{~s}$ for some hue-value combinations, although values of Chroma around 8 already correspond to vivid solid colours. For the samples at study, the values obtained for Chroma are very high, varying in the range 19.69-28.25 (Table 2). These values indicate that the cheeses evaluated showed purity colours.

The colour coordinate "Value" is exactly the same as L*, just divided by 10, varying from 1 to 10 and with the exact same interpretation as lightness, reason why it was not calculated.

\section{Variation of colour along the cheese production season}

Figure 1 presents the photos of the cheeses from different dairies between March and June (4 months).

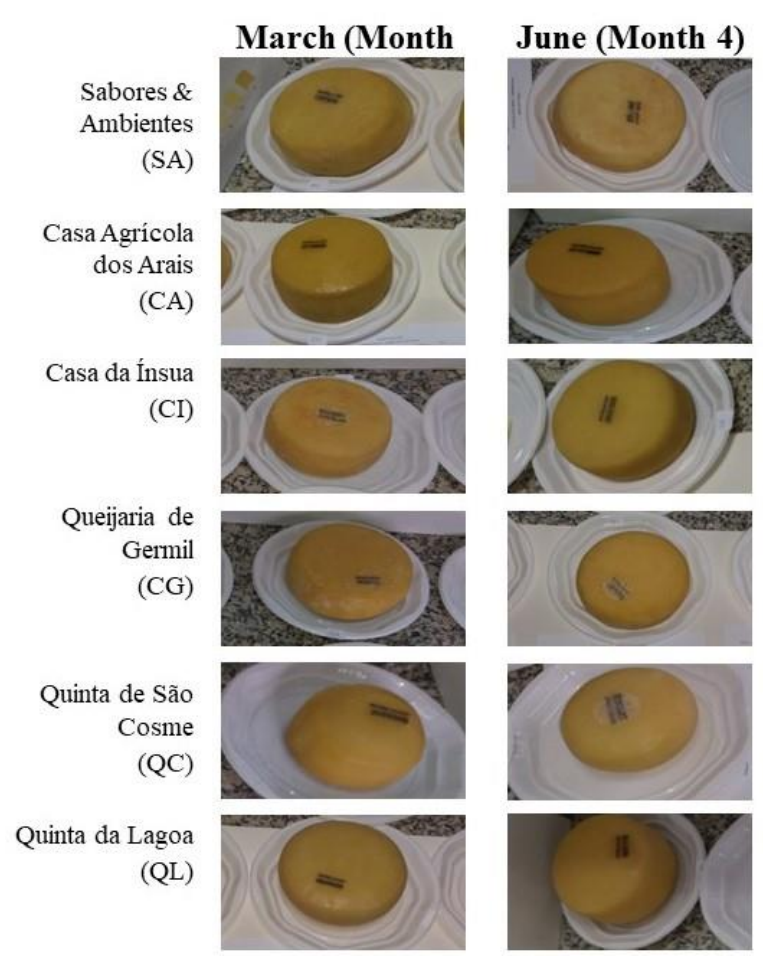

Figure 1. Cheeses between March and June

Figure 2 shows the variation along time of the colour coordinate $\mathrm{L}^{*}$, and the results for most dairies are not consistent with a unique trend along time.

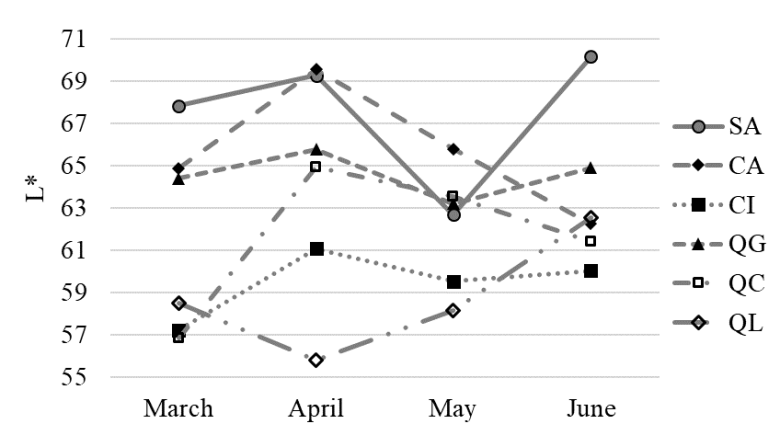

Figure 2. Variation of $L^{*}$ (lightness) along cheese production season

SA - Sabores \& Ambientes, CA - Casa Agrícola dos Arais, CI - Casa da Ínsua, QG - Queijaria de Germil, QC - Queijaria de São Cosme, QL - Quinta da Lagoa

For example, for the sample QL the measurement in March is clearly distinct from the increasing trend observed for the other dairies. In fact, while for most samples the global trend is to increase lightness, for sample QL the lightness decreases after the first month. Globally it is possible to see that the dairies with more uniform cheeses in terms of colour along the evaluation period considered were QG and CI. The evaluation period is spring, in which the climate tends to turn from cold to hot, and this might influence the pastures that feed the sheep, and therefore also the characteristics of the cheese, which in turn depend on the milk and also the maturation process. 
Regarding the variation of the opposing coordinate a* (Figure 3), there is a much higher concordance between the samples, just with exception of sample CI, whose values of greenness were excessive in the first two months of evaluation (March and April). For some samples the values of $\mathrm{a}^{*}$ remained practically unchanged (samples QC and QL), while for other there was a slight increasing trend (samples $\mathrm{SA}, \mathrm{CA}$ and $\mathrm{QG}$ ). This increase in the value of $\mathrm{a}^{*}$ means a decrease in the intensity of the green colouration towards an approximation of the limit of the red zone ( $a^{*}$ positive).

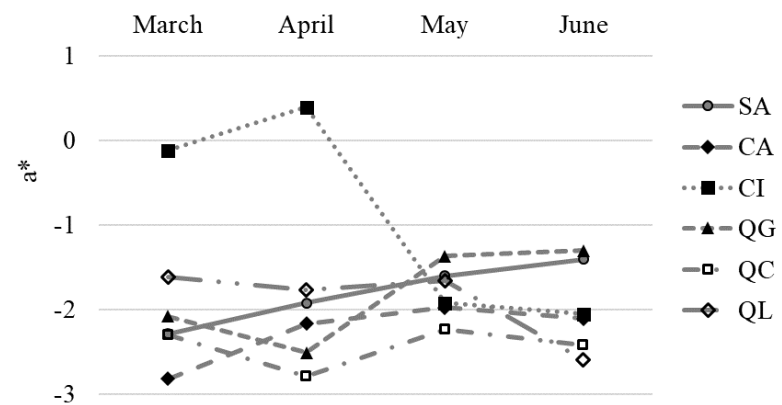

Figure 3. Variation of a* (greenness) along cheese production season

SA - Sabores \& Ambientes, CA - Casa Agrícola dos Arais, CI - Casa da Ínsua, QG - Queijaria de Germil, QC - Queijaria de São Cosme, QL - Quinta da Lagoa

The results obtained for $\mathrm{b}^{*}$ are presented in Figure 4, and they show that yellowness varied just slightly along the season, with the values for most samples being practically equal in March when compared with June (samples SA, QC, QG, CA). The sample QL was the one for which highest changes were observed, increasing the yellowness from around 20 to near 25 .

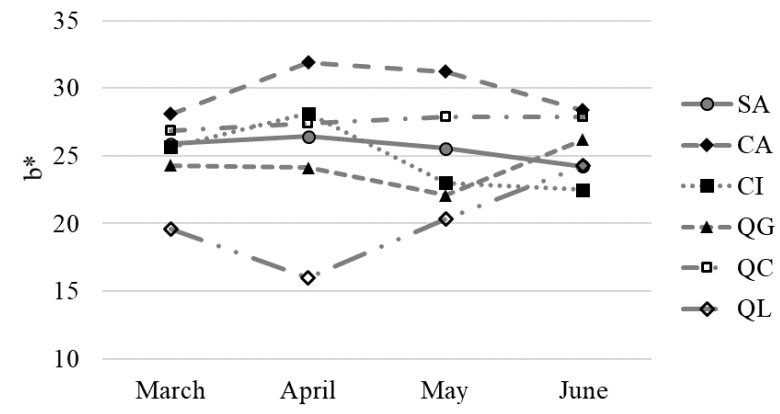

Figure 4. Variation of $b *$ (yellowness) along cheese production season

SA - Sabores \& Ambientes, CA - Casa Agrícola dos Arais, CI - Casa da Ínsua, QG - Queijaria de Germil, QC - Queijaria de São Cosme, QL - Quinta da Lagoa

Figure 5 reveals the change in the hue angle as comparing the beginning and the end of the evaluation period, respectively March and June. The results obtained indicate that the nature of the colour, chromaticity, remained practically unchanged for most samples, just with exception for sample SA whose value increased (changing in the direction green $\rightarrow$ cyan) and sample CI, whose value decreased (changing in the opposite direction (cyan $\rightarrow$ green).

The results in Figure 6 refer to the variation of Chroma evaluated between March and June. The results show that while for some samples the saturation or colour intensity decreased (SA, CA and CI) for sample QL it increased importantly while just slightly for samples QG and QC. This means that the cheeses produced in the dairies SA, CA and CI tend to develop a more faded colour while the others tend to become more vivid with time.

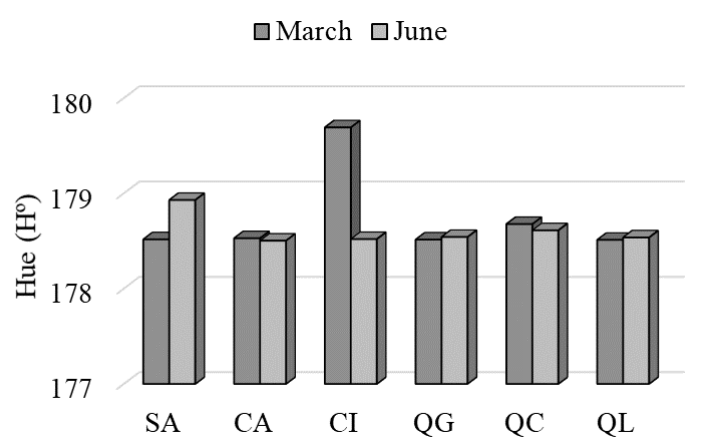

Figure 5. Changes in hue from the beginning to the end of the evaluation period

SA - Sabores \& Ambientes, CA - Casa Agrícola dos Arais, CI - Casa da Ínsua, QG - Queijaria de Germil, QC - Queijaria de São Cosme, QL - Quinta da Lagoa

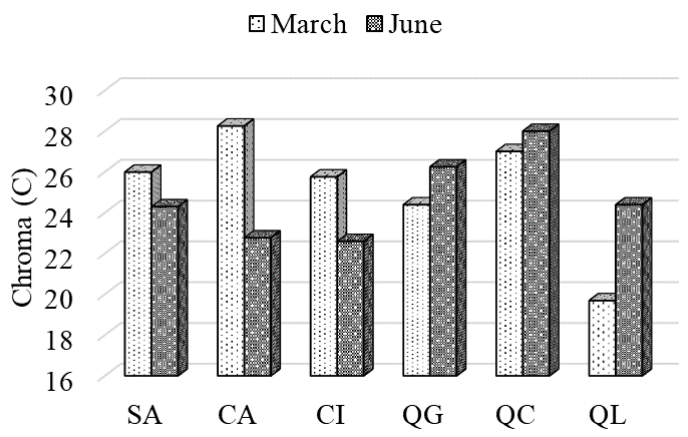

Figure 6. Changes in chroma from the beginning to the end of the evaluation period

SA - Sabores \& Ambientes, CA - Casa Agrícola dos Arais, CI - Casa da Ínsua, QG - Queijaria de Germil, QC - Queijaria de São Cosme, QL - Quinta da Lagoa

Because it is difficult to assess the actual colour changes when analysing individually the different colour coordinates, the total colour difference was calculated $(\Delta \mathrm{E})$, from the Cartesian coordinates $(\mathrm{L} * \mathrm{a} * \mathrm{~b} *)$. The values for colour difference are indicated in Figure 7 , expressing the total variations in colour along the milking season, i.e., from March to June. The results indicate that globally the samples QL, QC and CI were those whose colour changes the most during time, while sample QG was that where the colour remained more similar to the initial colour. 


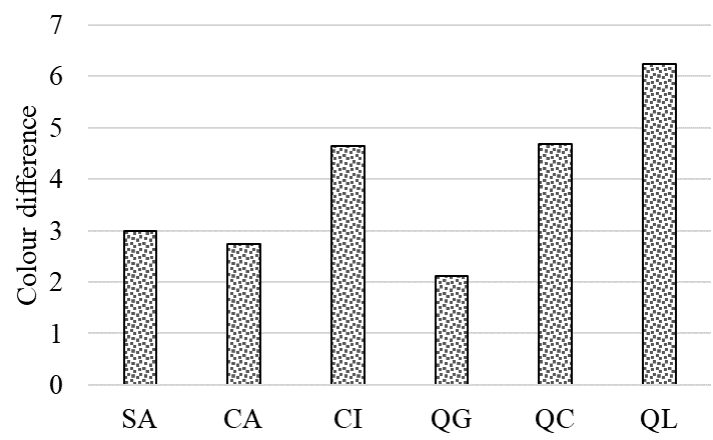

Figure 7. Total colour difference in the samples analysed after the evaluation period (June) in relation to the first month (March)

SA - Sabores \& Ambientes, CA - Casa Agrícola dos Arais, CI - Casa da Ínsua, QG - Queijaria de Germil, QC - Queijaria de São Cosme, QL - Quinta da Lagoa

According to the classification the colour difference for sample QG was practically unrecognizable (value very near 2), the differences for samples SA and CA were possible to recognize by an experienced observer (values close to 3) while the differences in samples CI, QC and QL were clear (values over 3.5 in the three cases).

\section{Conclusions}

The results obtained in this work showed that the colour characteristics of the Serra da Estrela Cheeses are quite different depending on the dairy where they are manufactured, for example dairy SA as compared with CI. Nevertheless, the values of the colour coordinates varied in a limited range, which means that the variations were acceptable having in consideration the nature of the traditional manufacture process associated with this PDO product.

However, along the milking season very important changes in colour took place, which is tolerable having in mind the nature of the physical-chemical changes produced during the cheese manufacture. Still, these changes were very much dependent of the dairy, as the results of total colour difference demonstrated.

\section{Acknowledgment}

The authors thank the FCT (Portuguese Foundation for Science and Technology), the Polytechnic Institute of Viseu and CI\&DETS for their support under project UID/Multi/04016/2016.

This work was prepared in the ambit of the project approved and financed by FCT with reference 02/SAICT/2016/23290, titled "QClasse: Caracterização e Valorização da autenticidade do QSE DOP e sua vocação para a promoção da Saúde”.

\section{References}

1. Carocho M., Barreira J.C.M., Bento A., FernándezRuiz V., Morales P., Ferreira I.C.F.R. (2016) Chestnut and lemon balm based ingredients as natural preserving agents of the nutritional profile in matured "Serra da Estrela" cheese. Food Chemistry, Vol. 204, p. 185-193.

2. Carocho M., Barros L., Barreira J.C.M., Calhelha R.C., Soković M., Fernández-Ruiz V., Buelga C.S., Morales P., Ferreira, I.C.F.R. (2016) Basil as functional and preserving ingredient in "Serra da Estrela" cheese. Food Chemistry, Vol. 2017, p. 51-59.

3. Cunha J.T., Ribeiro T.I.B., Rocha J.B., Nunes J., Teixeira J.A., Domingues L. (2016) RAPD and SCAR markers as potential tools for detection of milk origin in dairy products: Adulterant sheep breeds in Serra da Estrela cheese production. Food Chemistry, Vol. 211, p. 631-636.

4. Guiné R.P.F., Henriques F., Barroca M.J. (2014) Influence of drying treatments on the physical and chemical properties of cucumber. Journal of Food Measurement and Characterization, Vol. 8(3), p. 195-206.

5. Guiné R.P.F., Almeida I.C., Correia A.C., Gonçalves F.J. (2015) Evaluation of the physical, chemical and sensory properties of raisins produced from grapes of the cultivar Crimson. Journal of Food Measurement and Characterization, Vol. 9(3), p. 337-346.

6. Reis P.J.M., Malcata F.X. (2011) Ripening-related changes in Serra da Estrela cheese: A stereological study. Journal of Dairy Science, Vol. 94(3), p. 1223-1238.

7. Valdivia-López M.Á., Tecant, A. (2015) Chia (Salvia hispanica): A Review of Native Mexican Seed and its Nutritional and Functional Properties. Advances in Food and Nutrition Research, Vol. 75, p. 53-75. 